\title{
Palliative care services: Issues and public health challenges
}

\author{
Riawati Jahja
}

Research Associate, Lien Centre for Palliative Care (former), DUKE-NUS Graduate Medical School, Singapore.

\begin{abstract}
Trials have demonstrated improvement in patients' quality of life through palliative care services (PCS). However, many of these trials are limited by their research methodologies. PubMed, Cumulative Index to Nursing and Allied Health Literature (CINAHL) were searched to conduct a systematic review of review articles related to PCS from January 2001 to December 2011. The paper examined evidence from studies on PCS that aimed to improve elderly patients' end-of-life outcomes by i) systematically reviewing literature on models of palliative care (PC) delivery patients received; ii) exploring methodological issues surrounding recruitment of the patients, implementation of the studies and comparison of health care services; and iii) addressing the costs of care with/without a palliative program. Seventeen trials and three observational studies were selected from nine systematic review articles. Overall, early introduction of PC to patients following identification of their life-limiting conditions and needs requires an organized and coordinated care approach to ensure accessibility of these services. The ideal system that offers the potential of improving patients' quality of life is one that is integrated, interdisciplinary and holistic. Dying is commonly institutionalized; however, providing outreach programs that allow patients to die at their place of wish, such as domiciliary care, offers the potential of addressing the issue of ever-increasing health-care expenditure for the aged. However, further investigation is needed to evaluate the cost effectiveness of these programs. Methodological problems and ethical issues surrounding the study of terminally-ill patients necessitate that researchers use a combination of observational studies and surveillance system over time.
\end{abstract}

Keywords: Palliative care, Public health, Terminal care, End-of-life care, Research methodology.

\section{Introduction}

Globally, there are about 600 million people aged 60 years and above today, representing $11 \%$ of the world's population. ${ }^{1}$ By $2025-2030$, projections indicate that the population over 60 will be growing 3.5 times as rapidly as the total population $(2.8 \%$ as opposed to $0.8 \%){ }^{2}$ The population of older people is growing faster than the total population in practically all regions of the world and the difference in growth rates is increasing.

As the population ages, the gradual shift in the disease pattern from infectious diseases to degenerative conditions becomes more prominent in older people. ${ }^{3,4}$ Chronic and degenerative diseases are responsible for the majority of deaths worldwide, ${ }^{5}$ and are associated with greater health care utilization, ${ }^{6,7}$ and consequently, increasing costs. ${ }^{8}$ Evidence shows that the highest proportion of costs for care is incurred in the final years of life irrespective of age, and that total costs of care are greater in the elderly simply because this age group makes up a larger proportion of dying people. ${ }^{9-11}$ The use of health care services tends to concentrate at the end of $\operatorname{life}^{7}$ and has been increasing in the past two decades. ${ }^{12,13}$

Apart from that, concerns have been raised about the lack of information on the quality of life of institutionalized terminally-ill patients such as pain and symptoms control, and access to psychosocial and other multidisciplinary services. ${ }^{14,15}$ Studies have been done to show that a high

\section{Practice Points}

- Palliative care requires an integrated approach between institution and non-institution in order to deliver their services in a timely manner.

- Early introduction to palliative care services is important to ensure quality of life for the dying patients.

- Cost effectiveness of implementing palliative care programs should be evaluated in the local context.

- A combination of surveillance epidemiologic approach and observational studies offers a solution to the methodological problems and ethical issues.

- Appropriate methodologies allow results to be generalized and compared across nations.

number of acute care visits and inpatient hospital re-admissions indicate low quality of dying. ${ }^{14,16-18}$ While PCS provide end of life care, however, types of delivery (models) in PCS were individually reviewed, ${ }^{19-39}$ and very few systematic review addressing various models of palliative end-of-life care services delivery that resulted in various outcomes.

Correspondence: Dr. Riawati Jahja, Research Associate, Lien Centre for Palliative Care (former), DUKE-NUS Graduate Medical School, 8 College Road, Singapore 169857. Email: riawati.jahja@duke-nus.edu.sg, mvrjahja04@yahoo.com.

South East Asia Journal of Public Health 2012;2(2):5-15. (C) 2012 Jahja, publisher and licensee Public Health Foundation Bangladesh. This is an Open Access article which permits unrestricted non-commercial use, provided the original work is properly cited. 
Although employing rigorous research design in studies offer a high level of evidence, skepticism on the quality of outcomes research of terminally-ill patients has been an issue because researchers often encounter insuperable methodological problems in the process of applying research methods to the vulnerable populations. ${ }^{40-42}$ In this paper, we synthesize individual studies' results selected from a review of systematic reviews on models of PCS received by terminally-ill elderly that evidenced an improvement in their quality of life. Secondly, we explore methodological issues surrounding the recruitment of the patients in these studies, implementation of the studies' procedure and comparison of different health care services. Thirdly, we discuss the health care costs with or without a PC program. Finally, we provide a recommendation to apply an epidemiologic approach to address the problems.

\section{Materials and methods}

We carried out this systematic review according to the frameworks for reviews of palliative care ${ }^{43}$ and end of life care. ${ }^{44}$ The conduct of this systematic review was guided by the Preferred Reporting Items for Systematic Reviews (PRISMA) ${ }^{45}$ and Cochrane Collaboration of reporting SRs. ${ }^{46}$

\section{Definition}

The World Health Organization defines PC as: 'an approach that improves the quality of life of patients and their families facing the problem associated with lifethreatening illness, through the prevention and relief of suffering by means of early identification and impeccable assessment and treatment of pain and other problems, physical, psychosocial and spiritual ${ }^{47}$ Herein, we define an institution that refers to any emergency department, outpatient clinic, and hospital, and a noninstitution is taken place at patients' home, hospice, nursing home or community hospital.

\section{Search strategy}

A systematic literature search on PCS published in the last eleven years (January 2001 to December 2011) was undertaken using PubMed, Cumulative Index to Nursing and Allied Health Literature (CINAHL). The search strategy focused on three keywords: palliative care, hospice care and terminal care, and restricted to review articles in English. EndNote software was used to manage the citation information and coding articles. An earlier study ${ }^{48}$ revealed that comprehensive grey literature search was generally unsuccessful at obtaining unpublished studies, and it is not an efficient methodology in palliative care systematic reviews, thereby they were ignored in this systematic review.

\section{Selection criteria and process}

In first criteria, we included studies reporting evidence of PCS that related to patients' outcomes of their quality of life, healthcare costs and place of death. Second criteria aimed to select elderly aged 60 years and above with life-limiting conditions, who were being institutionalized or non-institutionalized.
There were two stages in the selection of studies; first stage was to select systematic review articles that met the first inclusion criteria and grading evidence. Second stage was to identify individual studies from reference lists of the selected systematic reviews. Subsequently, the identified individual studies were reviewed and sorted to obtain macro-level of randomized controlled trials (RCTs) and observational studies. We excluded studies that reported evidence of PCS using surrogates for the patients' outcomes, qualitative and descriptive designs. Lastly, the sorted individual studies that fit into the second criteria and grading evidence were selected for this systematic review.

\section{Data extraction}

Three research staff (a research fellow, a research associate and a research assistant) independently reviewed the results from the primary search of titles, followed by abstracts and full paper searches (Figure 1). A form was used to extract information on patient's outcomes receiving PCS in a standardized manner guided by $\mathrm{PICO}^{45}$ ${ }_{-46}^{-4}$ (Population, Intervention, Comparison, and Outcome) elements for all articles under full-text review. The following are information included in the form: the types of patient' outcome and study; country and setting; details on health services delivery and methodological issues and procedure; measures of healthcare cost; measures of quality of life including pain relief, other symptoms relief (anxiety, depression), satisfaction with care; magnitude of effect and association of the outcomes.

\section{Grading}

When full-text review was carried out, each study was graded on its level of evidence (LOE) according to the Scottish Intercollegiate Guidelines Network (SIGN) ${ }^{49}$ The selection of systematic review article was graded $1+$ and above, and individual study was graded $\geq 1+$ for $\mathrm{RCT}$ and $\geq 2+$ for observational studies.

\section{Outcomes measures}

Primary outcome was patients' quality of life that was most frequently reported and measured subjectively. There are several components of quality of life in palliative care including satisfaction with care, patient' wellbeing, pain and other symptoms (anxiety, mood, depression) relief. ${ }^{41}$ Investigators might use different instrument to measure same component of the quality of life. Secondary outcome was health care costs, which was not specific due to different measurements in each study. Tertiary outcome was the proportion of terminally-ill patients who died at home. A study could investigate a model of PCS in relation to a single outcome or more.

\section{Result}

The detailed history of search results is shown in Figure 1. From a total of 2,425 citations retrieved from electronic literature searches; we have included 9 systematic reviews ${ }^{40,42,50-56}$ that met the first inclusion criteria. These 9 systematic reviews covered 78 individual studies specific to the outcomes in which study design is 
either macro-level of RCT or observational studies.

Among 78 individual studies, 8 met the second criteria (Table 1). Owing to this small number of studies resulted for patients aged $\geq 60$ years and above, and the review of reference lists yielded no paper that met the second inclusion criteria, we then, included twelve studies on patients at all ages when the study design is RCT (Table 2). We excluded 58 studies, which did not meet pre-defined criteria in the grading evidence, or when investigators reported that they had encountered insuperable problems with high risk of biases in their study process. Thus, a total of 20 studies were included in this systematic review.

Study descriptions

Of the total 20 studies, ${ }^{19-25,27-39}$ all were carried out in western countries, mostly in USA, ${ }^{19,21-25,27-30,35,37,39}$ the rest of seven studies were from $\mathrm{UK}^{31,38}$, Australia ${ }^{32}$, Spain $^{20}$, Canada ${ }^{36}$ and Norway. ${ }^{33-34}$ The size of the study population in two retrospective cohort studies ${ }^{19,21}$ was 5,774 and 183,742 respectively while in one casecontrol study ${ }^{20}$ was 155 , case-to-control ratio was 1:2.5.

\section{2,425 citations retrieved from literature searches}

\begin{tabular}{|l}
$\longrightarrow$ \\
$\longrightarrow$ Duplicates excluded $(n=129)$ \\
\hline Excluded as titles didn't match first criteria $(n=1,954)$
\end{tabular}

Abstracts checked $(n=342)$

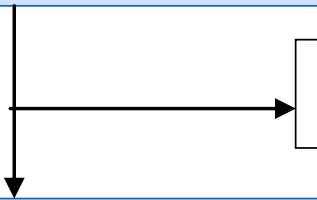

Excluded as abstracts didn't match first criteria, were narrative reviews, non-systematic reviews $(n=226)$

Full papers checked $(n=116)$

Excluded on the basis of full text review, LOE $<1+(n=107)$

Systematic reviews selected $(n=9)$

Individual articles identified from reference lists of the systematic reviews on the basis of title that met the first inclusion criteria $(n=151)$

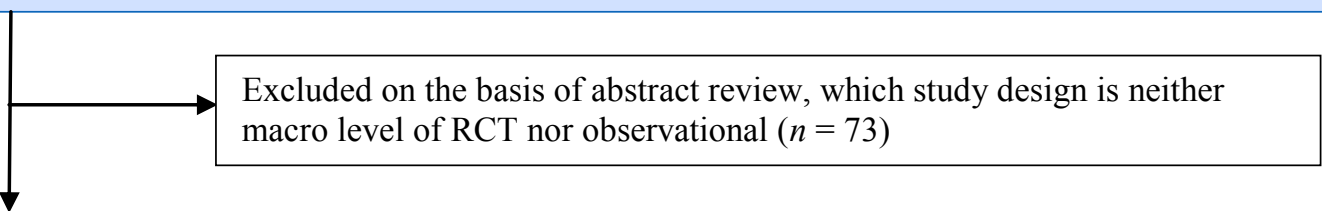

Individual articles identified from reference lists of the systematic reviews on the basis of abstract review $(n=78)$

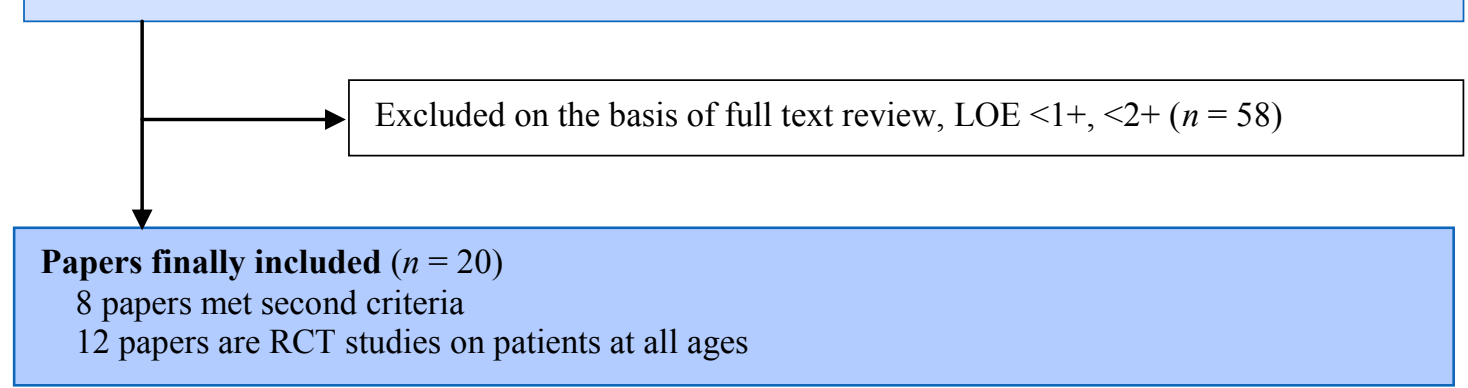

Figure 1: Flowchart for search strategy of studies on palliative care

South East Asia Journal of Public Health 2012;2(2):5-15. 
Table 1: Models of palliative services delivery elderly patients received (aged $\geq 60$ years) from institutions and non-institutions

\begin{tabular}{|c|c|c|c|c|c|}
\hline Studies & $\begin{array}{c}\text { Models of } \\
\text { delivery }\end{array}$ & $\begin{array}{l}\text { Design, Country, } \\
\text { Comparison group }\end{array}$ & Outcomes $^{\mathrm{a}}$ & Measurements ${ }^{b}$ & LOE \\
\hline Allen et $a l^{23}$ & $\begin{array}{l}\text { Caregiver ap- } \\
\text { proach; } \\
\text { Family-focused } \\
\text { intervention }\end{array}$ & $\begin{array}{l}\text { RCT, USA; } \\
\text { Non-specific support } \\
\text { to families via phone } \\
\text { call }\end{array}$ & $\begin{array}{l}\text { No difference in pain inten- } \\
\text { sity } \\
\text { Decrease in depressive } \\
\text { symptoms } \\
\text { No difference in well-being }\end{array}$ & $\begin{array}{l}\text { ESAS } \\
\text { CES-D } \\
\text { SWB }\end{array}$ & $1+$ \\
\hline $\begin{array}{l}\text { Brumley et } \\
\text { al. }^{25}\end{array}$ & $\begin{array}{l}\text { Outreach PC pro- } \\
\text { gram; } \\
\text { Interdisciplinary } \\
\text { approach; } \\
\text { 24-hour on-call } \\
\text { service }\end{array}$ & $\begin{array}{l}\text { RCT, USA; } \\
\text { Usual care }\end{array}$ & $\begin{array}{l}\text { Increase in satisfaction with } \\
\text { care } \\
\text { Increase in the likelihood of } \\
\text { terminally-ill patients dying } \\
\text { at home according to their } \\
\text { wish } \\
\text { Reduction in hospital admis- } \\
\text { sions } \\
\text { Reduction in costs of medi- } \\
\text { cal care }\end{array}$ & $\begin{array}{l}\text { RGS } \\
98 \% \text { information on } \\
\text { the place of death } \\
\text { data were available } \\
\text { Database } \\
\text { Total costs }\end{array}$ & $1++$ \\
\hline $\begin{array}{l}\text { Detering et } \\
\mathrm{al}^{32}\end{array}$ & $\begin{array}{l}\text { Introduce and } \\
\text { communicate ACP }\end{array}$ & $\begin{array}{l}\text { RCT, Australia; } \\
\text { Usual care }\end{array}$ & $\begin{array}{l}\text { Increase in overall satisfac- } \\
\text { tion } \\
\text { with care }\end{array}$ & $\begin{array}{l}\text { Discharge question- } \\
\text { naire }\end{array}$ & $1+$ \\
\hline Gozalo et al. $^{19}$ & $\begin{array}{l}\text { PC program } \\
\text { (hospice care) in } \\
\mathrm{NH}\end{array}$ & $\begin{array}{l}\text { Retrospective cohort } \\
\text { study, USA; } \\
\text { NH residents did not } \\
\text { receive any PC pro- } \\
\text { gram, i.e. hospice care }\end{array}$ & $\begin{array}{l}\text { Reduction in health care } \\
\text { expenditure }\end{array}$ & $\begin{array}{l}\text { Total Medicare/ } \\
\text { Medicaid expenditure } \\
\text { in the last month of } \\
\text { life }\end{array}$ & $2+$ \\
\hline Gozalo et $a l .^{21}$ & $\begin{array}{l}\text { PC program } \\
\text { (hospice care) in } \\
\mathrm{NH}\end{array}$ & $\begin{array}{l}\text { Retrospective cohort } \\
\text { study, USA; } \\
\text { Non-hospice enrol- } \\
\text { ment for long- and } \\
\text { short-stay residents in } \\
\text { nursing homes }\end{array}$ & $\begin{array}{l}\text { Reduction in hospitalization } \\
\text { rates in the last month of life }\end{array}$ & Databases & $2+$ \\
\hline Molloy et al. ${ }^{36}$ & $\begin{array}{l}\text { Communicate and } \\
\text { complete AMD } \\
\text { for residents in } \\
\text { nursing homes }\end{array}$ & $\begin{array}{l}\text { RCT, Canada; } \\
\text { Offered no AMD }\end{array}$ & $\begin{array}{l}\text { Reduction in hospital admis- } \\
\text { sions } \\
\text { Reduction in health care } \\
\text { costs }\end{array}$ & $\begin{array}{l}\text { Case-mix index } \\
\text { MOH price list } \\
\text { Total costs } \\
\text { (healthcare use and } \\
\text { unit costs of services) }\end{array}$ & $1+$ \\
\hline $\begin{array}{l}\text { Serra-Prat } e t \\
a l^{20}\end{array}$ & $\begin{array}{l}\text { Outreach PC pro- } \\
\text { gram }\end{array}$ & $\begin{array}{l}\text { Case-control study, } \\
\text { Spain; } \\
\text { Standard care }\end{array}$ & $\begin{array}{l}\text { Reduction in institutional } \\
\text { admissions, and emergency } \\
\text { and outpatient visits } \\
\text { More cost-savings to health } \\
\text { care }\end{array}$ & $\begin{array}{l}\text { Identified from the } \\
\text { death certificates } \\
\text { used by institutional } \\
\text { and non-institutional } \\
\text { services } \\
\text { Direct costs }\end{array}$ & $2+$ \\
\hline Zimmer et ll. $^{28}$ & $\begin{array}{l}\text { Outreach PC pro- } \\
\text { gram; Interdisci- } \\
\text { plinary approach; } \\
\text { 24-hour service } \\
\text { availability }\end{array}$ & $\begin{array}{l}\text { RCT, USA; } \\
\text { Standard care }\end{array}$ & $\begin{array}{l}\text { More dying patients died at } \\
\text { place of wish, e.g. home } \\
\text { Increase satisfaction with } \\
\text { care } \\
\text { Reduction in use of re- } \\
\text { sources } \\
\text { No difference in costs of } \\
\text { care }\end{array}$ & $\begin{array}{l}\text { Follow-up } \\
\text { Patient satisfaction } \\
\text { questionnaire } \\
\text { HSU diary } \\
\text { Costs of day services }\end{array}$ & $1+$ \\
\hline
\end{tabular}

Keys: ACP - Advance Care Planning; AMD - Advance Medical Directive; CES-D - Center for Epidemiological Studies Depression scale; ESAS - Edmonton Symptom Assessment Scale; HSU - Health service utilization; LOE - Level of Evidence; MOH - Ministry of Health; NH - Nursing home; PC - Palliative care; QoL - Quality of life; RCT - Randomized controlled trial; RGS - Reid-Gundlach Satisfaction with services instrument; SWB - Subjective well-being scale. ${ }^{a}$ All improved outcomes are statistically significant, i.e., $p<0.05$, or not crossing the unity of the $95 \%$ confidence interval. ${ }^{\mathrm{b}}$ Instruments for measuring quality of life. Data of health care utilization and costs were collected from various data sources and calculated according to the respective sources. Information on the place of death was collected from various sources across studies with calculation of proportion of people who died at home.

All studies included men and women, and incorporated life-threatening illnesses such as cancer and end-stage of chronic diseases (congestive heart failure, chronic obstructive pulmonary disease, renal failure, motor neuron diseases, etc). Two studies ${ }^{28-29}$ included patients with both terminal and non-terminal diseases. Overall 
Table 2: Models of palliative services delivery patients received (at all ages) from institutions and non-institutions

\begin{tabular}{|c|c|c|c|c|c|}
\hline Studies & Models of delivery & $\begin{array}{l}\text { Design, Country, } \\
\text { Comparison group }\end{array}$ & Outcomes $^{\mathrm{a}}$ & $\begin{array}{l}\text { Measure- } \\
\text { ment }^{b}\end{array}$ & LOE \\
\hline $\begin{array}{l}\text { Aiken et } \\
a l .{ }^{22}\end{array}$ & $\begin{array}{l}\text { Outreach PC program } \\
\text { Integrated palliative } \\
\text { care with other medical } \\
\text { services }\end{array}$ & $\begin{array}{l}\text { RCT, USA; } \\
\text { Usual care }\end{array}$ & $\begin{array}{l}\text { Lower symptom dis- } \\
\text { tress } \\
\text { Improve quality of life } \\
\text { No difference in re- } \\
\text { source use }\end{array}$ & $\begin{array}{l}\text { MSAS } \\
\text { SF-36 }{ }^{\mathrm{TM}} \mathrm{HS} \\
\text { Database }\end{array}$ & $1+$ \\
\hline $\begin{array}{l}\text { Bakitas et } \\
\text { al. }^{24}\end{array}$ & $\begin{array}{l}\text { Coordinated care } \\
\text { Multidisciplinary ap- } \\
\text { proach } \\
\text { Outreach PC program } \\
\text { Telephone-based ap- } \\
\text { proach }\end{array}$ & $\begin{array}{l}\text { RCT, USA; } \\
\text { Customary and pri- } \\
\text { vate sector care }\end{array}$ & $\begin{array}{l}\text { Improve quality of life } \\
\text { Reduce mood symp- } \\
\text { toms } \\
\text { No difference in symp- } \\
\text { toms intensity (pain, } \\
\text { nausea, anxiety, etc) } \\
\text { No difference in re- } \\
\text { source use }\end{array}$ & $\begin{array}{l}\text { FACIT-Pal } \\
\text { CES-D } \\
\text { ESAS } \\
\text { Chart review }\end{array}$ & $1+$ \\
\hline $\begin{array}{l}\text { Du Pen et } \\
a l .{ }^{27}\end{array}$ & $\begin{array}{l}\text { A guideline for cancer } \\
\text { pain management }\end{array}$ & $\begin{array}{l}\text { RCT, USA; } \\
\text { Received standard- } \\
\text { practice pain man- } \\
\text { agement }\end{array}$ & Reduce pain intensity & BPI & $1+$ \\
\hline $\begin{array}{l}\text { Engelhardt } \\
\text { et al. }{ }^{30}\end{array}$ & $\begin{array}{l}\text { Outreach PC program } \\
\text { Coordinated approach } \\
\text { in a multidisciplinary } \\
\text { care }\end{array}$ & $\begin{array}{l}\text { RCT, USA; } \\
\text { Usual care }\end{array}$ & $\begin{array}{l}\text { Increase satisfaction } \\
\text { with care } \\
\text { No difference in health } \\
\text { care costs }\end{array}$ & $\begin{array}{l}\text { Investigator- } \\
\text { constructed } \\
10 \text {-item scale } \\
\text { Database } \\
\text { Average cost } \\
\text { per case }\end{array}$ & $1+$ \\
\hline $\begin{array}{l}\text { Grande et } \\
a l .{ }^{31}\end{array}$ & Outreach PC program & $\begin{array}{l}\text { RCT, UK; } \\
\text { Standard care }\end{array}$ & $\begin{array}{l}\text { Patients were more } \\
\text { likely to die at home }\end{array}$ & $\begin{array}{l}\text { Death certifi- } \\
\text { cation }\end{array}$ & $1+$ \\
\hline $\begin{array}{l}\text { Hughes et } \\
\text { al. }^{29}\end{array}$ & $\begin{array}{l}\text { Outreach PC program } \\
\text { 24-hour service avail- } \\
\text { ability }\end{array}$ & $\begin{array}{l}\text { RCT, USA; } \\
\text { Customary and pri- } \\
\text { vate care }\end{array}$ & $\begin{array}{l}\text { Improve quality of life } \\
\text { in term of pain } \\
\text { No difference in } \\
\text { resource use } \\
\text { Higher costs of care }\end{array}$ & $\begin{array}{l}\text { HR-QoL } \\
\text { (MOS SF-36) } \\
\text { Institution's } \\
\text { databases } \\
\text { Total costs }\end{array}$ & $1+$ \\
\hline $\begin{array}{l}\text { Jordhöy et } \\
a l .{ }^{34}\end{array}$ & $\begin{array}{l}\text { Multidisciplinary ap- } \\
\text { proach in a coordinated } \\
\text { care }\end{array}$ & $\begin{array}{l}\text { RCT, Norway; } \\
\text { Conventional care }\end{array}$ & $\begin{array}{l}\text { More patients dying at } \\
\text { home }\end{array}$ & Follow-up & $1+$ \\
\hline $\begin{array}{l}\text { Jordhöy et } \\
a l .{ }^{33}\end{array}$ & $\begin{array}{l}\text { Multidisciplinary ap- } \\
\text { proach in a coordinated } \\
\text { care }\end{array}$ & $\begin{array}{l}\text { RCT, Norway; } \\
\text { Conventional care }\end{array}$ & $\begin{array}{l}\text { No difference in } \\
\text { quality of life }\end{array}$ & $\begin{array}{l}\text { EORTC } \\
\text { QLQ-C30 }\end{array}$ & $1+$ \\
\hline $\begin{array}{l}\text { Keefe et } \\
a l . .^{35}\end{array}$ & $\begin{array}{l}\text { Caregiver approach } \\
\text { Partner-guided cancer } \\
\text { pain management }\end{array}$ & $\begin{array}{l}\text { RCT, USA; } \\
\text { Usual care }\end{array}$ & $\begin{array}{l}\text { Reduce pain intensity } \\
\text { No difference in QoL }\end{array}$ & $\begin{array}{l}\text { BPI } \\
\text { FACT-G, v4 }\end{array}$ & $1+$ \\
\hline $\begin{array}{l}\text { Northouse } \\
\text { et al. }\end{array}$ & $\begin{array}{l}\text { Caregiver approach } \\
\text { Family-focused pro- } \\
\text { gram of patient-spouse } \\
\text { dyads }\end{array}$ & $\begin{array}{l}\text { RCT, USA; } \\
\text { Standard clinic care }\end{array}$ & $\begin{array}{l}\text { No difference in quality } \\
\text { of life } \\
\text { No difference in symp- } \\
\text { tom distress }\end{array}$ & $\begin{array}{l}\text { MOS SF-12 } \\
\text { FACT-G \& } \\
\text { FACT-P } \\
\text { OSQ }\end{array}$ & $1+$ \\
\hline
\end{tabular}




\begin{tabular}{|l|l|l|l|l|l|}
\hline $\begin{array}{l}\text { Raftery } \text { et } \\
a l^{38}\end{array}$ & $\begin{array}{l}\text { Coordinated care in the } \\
\text { existing hospital-based } \\
\text { home care (outreach PC } \\
\text { program) }\end{array}$ & $\begin{array}{l}\text { RCT, UK; } \\
\text { Usual care }\end{array}$ & Lower service use & $\begin{array}{l}\text { Patients' case notes, } \\
\text { non-institution' } \\
\text { records, local } \\
\text { thority data } \\
\text { Routine, total direct } \\
\text { and indirect costs }\end{array}$ & $1+$ \\
\hline $\begin{array}{l}\text { Temel } e t \\
a l .\end{array}$ & $\begin{array}{l}\text { Early introduction PC } \\
\text { program }\end{array}$ & $\begin{array}{l}\text { RCT, USA; } \\
\text { Standard care }\end{array}$ & $\begin{array}{l}\text { Better quality of life } \\
\text { Low rates of depres- } \\
\text { sion }\end{array}$ & $\begin{array}{l}\text { FACT-L } \\
\text { HADS } \\
\text { PHQ-9 }\end{array}$ & $1+$ \\
\hline
\end{tabular}

Keys: BPI - Brief Pain Intensity scale; CES-D - Center for Epidemiological Studies Depression scale; ED - Emergency department; EORTC QLQ-C30 - the European Organization for Research and Treatment of Cancer Quality of Life Questionnaire-C30; ESAS - Edmonton Symptom Assessment Scale; FACIT-Pal - Functional Assessment of Chronic Illness Therapy-Palliative care scale; FACT-G v4 - Functional Assessment of Cancer Therapy-General version4; FACT-P - Functional Assessment of Cancer Therapy-Prostate specific; FACT-L - Functional Assessment of Cancer Therapy-Lung; HADS - Hospital Anxiety and Depression scale; HR-QoL - Health Related Quality of Life scale; LOE - Level of Evidence; LOS - Length of stay; MOS SF-36 - Medical Outcomes Study, short form, 36-items; MSAS - Memorial Symptom Assessment Scale; OSQ - Omega Screening Questionnaire; PC - Palliative care; PHS-9 Patient Health Questionnaire; QoL - Quality of life; RCT - Randomized controlled trial; SF-36 ${ }^{\mathrm{TM}}$ HS - SF-36 ${ }^{\mathrm{TM}}$ Health Survey; ${ }^{a}$ All improved outcomes are statistically significant, i.e., $p<0.05$ or not crossing the unity of the $95 \%$ Confidence Interval. ${ }^{b}$ Instruments for measuring quality of life. Data of health care utilization and costs were collected from various data sources and calculated according to the respective sources. Information on the place of death was collected from various sources across studies with calculation of proportion of people who died at home.

prognoses for life expectancy were less than 2 years, except a study ${ }^{37}$ on prostate cancer that was more than 2 years.

\section{The models of palliative care services}

We grouped the models of care derived from the 20 selected studies into three categories:

\section{Category 1: Intensive palliative care programs}

This category focused on intensified PC programs such as: (a) outreach programs providing home and community PCS by any institution-based, (b) integrated PCS with other health service providers, for example between hospital and hospice/home PCS/community PCS, (c) 24-hour PCS availability, (d) a telephone-based approach, (e) early introduction to PCS for patients with new diagnosis of life limiting disease, (f) introduce and communicate advanced care plan (ACP) and subsequently complete advance medical directive (AMD) at any institution base, and (g) clinical practice guidelines. A study might have one or more intensive PC programs.

\section{Category 2. Team-based approach}

In this category, the studies focused on manpower expertise. The models of palliative services delivery are interdisciplinary, multidisciplinary and coordinated care such as hospital-based home care.

\section{Category 3. Caregiver approach}

The models of care under this category are familyfocused intervention, family-focused programs on patient-spouse dyads and partner-guided pain management. This approach was organized by a palliative care service provider.

\section{Discussion}

Effectiveness of the models of palliative care services It has been recognized that routine PCS within the existing medical care structure at the time of the study were found to be inadequate in meeting needs of the patients, underused and costly in providing end of life care ${ }^{22-}$ 25,27,29-39 and these underlie the need for more effective palliative programs for those in the final stage of life. The systematic literature review shows that the models of service delivery were intensified palliative programs providing the routine PCS, and were found to be effective in improving terminally-ill patients' outcomes. Studies where patients were not newly diagnosed for life-limiting illnesses, the integrated PC approach between institution and non-institution improved patients' quality of life and lower symptom distress. ${ }^{22,24}$ Nevertheless, early introduction of PCS to patients with a new diagnosis of life-limiting conditions also showed increase of the patients' quality of life and reduction on symptoms of depression. ${ }^{39}$ This implies that timely referral to PCS that incorporates a coordinated approach between institution and non-institution, helps to further improve patient's quality of life.

The models of palliative services delivery that aimed to improve quality of life in terms of satisfaction with care improved significantly for those enrolled in the intervention arm in the related studies. ${ }^{25,28,30,32}$ This was mainly due to the intensified palliative programs that focused on intervention groups and attended to their needs. These programs may also be applied, with the same results, to other components in quality of life, such as mood (depression), as these programs targeted psychosocial and emotional well-being through providing intensive support. Nonetheless, in terms of reducing 
pain and other symptoms relief, these programs have results that were skewed in opposite directions: either no difference or an improvement in the intensity of symptoms. In the studies where no difference was found, that the result were due to the patients' pain was not being properly addressed through the intervention program. ${ }^{23,33-34}$ The other reason given was the possibility that some patients in the study groups had been referred to seek consultation from other specialists when their pain was not relieved or when they reported other symptoms. ${ }^{24}$ One study, which resulted in improvement in the relief of pain and other symptoms in the intervention group, had focused only on the intensified palliative program per se, however it might not probably include covariates that relieved pain and other symptoms in its analysis. ${ }^{29}$ The mixing of effects among the intervention, outcome and a confounding variable distorts the relationship between an intervention and an outcome if no adjustment is made for the third variable. Apparently, studies that included pain management and medication use in their intensive palliative program showed positive results in reducing pain and intensity of other symptoms in the intervention group compared to the control. $^{22,27,35,39}$ Nevertheless, poor documentation on the use of pain medication may divert findings away from the true estimate. ${ }^{27}$

It is also noteworthy to highlight that however intensive a palliative program is, it should also be evaluated for its suitability to its target groups. In a study that targeted patients with prostate cancer using a model of service delivery focused on patient-spouse dyads, the study had adapted intervention from a breast-cancer program, and found no difference in symptom relief between the intervention group and control group. ${ }^{37}$ The program might have had more positive results had it focused on the relief of prostate-specific symptoms.

\section{Methodological issues}

Among the $17 \mathrm{RCTs},{ }^{22-25,27-39} 16$ are at low risk of bias, LOE: $1+$ and one study ${ }^{25}$ is very low on the risk, LOE: $1++$ (Tables 1 and 2). Those 16 RCTs with a low risk of bias encounter problems that illustrate the difficulties in recruitment and achieving the required sample size mainly because many terminally-ill patients die during the study period before reaching their full life expectancy, ${ }^{22,24,28,31-32,39}$ others reported being limited by a small sample size. ${ }^{23,35-37}$

In the case of treatment compliance in a drug trial, especially in palliative care research on the terminally-ill elderly, some patients' severe conditions or misconception, prevent them from adhering exactly to the protocol as a trial proceeds. ${ }^{27,32,35-36}$ Randomized assignment of subjects to either the treatment or control group could be violated due to ethical considerations, such as when there is a need for patients in the control group to receive a more intensive palliative program because of their conditions, ${ }^{24,28-31,39}$ or because the number of subjects in the intervention group are too few to obtain meaningful measurements. ${ }^{38}$ Others had no proper allocation concealment, thus compromising the randomization of subjects to treatment/control group. ${ }^{23-24,29,33-34,39}$
Poor quality of reporting of RCTs in palliative care is another issue in the methodology; examples include insufficient descriptions of the randomization process, allocation concealment, the use of an intention-to-treat analysis and no description of sample size calculation. $^{23,28-30,33-38}$

\section{Case definition}

Allocation based on prognosis of life expectancy before randomization could be a potential bias when drop-out occurred in both arms different from the estimation. The two groups might not be comparable: the control group might have more ill patients who consumed more palliative services than the intervention group. ${ }^{38}$

\section{Instruments}

Variations occurred with regard to the subjective measurement of quality of life. Studies of terminally-ill patients in palliative care relied upon self-reports; but quality of life comprises several components of satisfaction with care, pain- and other symptoms-relief, and dying at the place of wish. Each component of quality of life could be assessed by different instruments across studies yielded on heterogeneous results on the quality of life.

Diverse instruments have been used in assessing the components of quality of life and validated in independent populations, frequently showing good discriminatory ability, with the exception of one instrument that was constructed by an investigator measuring satisfaction with care. This study did not mention about the instrument validation procedure other than reliability, measured at enrollment using Cronbach's alpha. ${ }^{30}$

\section{Healthcare costs on palliative programs}

Despite the intention of outreach palliative programs to provide domiciliary care that allows more dying patients to die at their locale of preference, and to reduce healthcare use and costs, ${ }^{25}$ studies on such a model of service delivery do not always demonstrate the desired results, ${ }^{22,24,28-30}$ or sometimes even result in higher costs of implementing the model of care. ${ }^{29}$ In one study, ${ }^{29}$ which included both non-terminal and terminally-ill patients, higher costs of care could be related to the incorrect sequence in conducting the randomization process and the results might be biased toward the null hypothesis of the study. Stratification between terminal and non-terminal status should come first, followed by randomization, and then followed by the allocation or assignment in each stratum. The explanation was that enrolment of the non-terminally-ill patients — who tended to spend more on visiting emergency departments and utilizing hospitals compared to home-bound terminally-ill elderly, who depended on the home-health -care team visits - could yield more expenses in the intervention. However, in a study that performed the correct sequence of randomization following the stratification by terminal-illness status, ${ }^{28}$ neither any decrease in use of PC nor in costs was found, despite its intensive program offering a 24-hour service to the terminally-ill patients in the intervention group to ensure that they stayed and died at home. It could be that expenses for 
the home-bound patients' caretakers were not taken into consideration in the costs of care that might offset the effect of intervention, resulting in no significant difference made to the overall costs of health services. Such informal care giving was not without cost. ${ }^{57}$ Studies should be conducted to assess whether there is a reduce use of emergency department and/or hospital when terminally-ill patients are provided with 24 -hour home PCS

Furthermore, in the study of comparing intensive homebased PC and customary care, ${ }^{29}$ higher costs of care of implementing the intensive palliative program might be due to greater expenditure on care-giving services for patients with severe functional disability. Doing so meant that the latter was factored into the total cost of care, but with no difference in the pattern of readmissions and disease stratification. Another issue was that staff replacement during the study period was another possible factor that could have contributed to higher costs because new staff were not well versed with the intervention model and needed longer time to carry out the procedures of the study. $^{29}$

Using more comprehensive data sources such as databases in capturing data on resource use and costs instead of charts may generate a more accurate reflection of the cost effectiveness of an intervention. ${ }^{24}$ Moreover, there might be some costly aspects of care that an investigator was unable to characterize because of poor documentation and quality of data on medical claims. ${ }^{22}$ In addition, investigators should conduct a longitudinal study for it is an important factor in detecting cost differences over time. ${ }^{30}$

Studies that included hospice care in their exposure ${ }^{19,21}$ or intervention $^{25}$ resulted in reducing hospital admission and health-care expenditures, as supported by an earlier study stating that savings from the use of hospice care occur mostly in the last month of the patient's life. ${ }^{58}$ In contrast, a study, ${ }^{30}$ which included hospice services in its intensive coordinated palliative program showed no difference in health-care cost between the intervention group and those who received the usual care; but the study had positive results in terms of increased satisfaction with care. This study bore the extra cost of the manpower required to coordinate and run the program, and of training staff to conduct the communication intervention for end-of-life plan. Another study, ${ }^{22}$ which has a distinctive palliative service delivery of a hospice care that aimed to shift dying patients from utilizing institutions into home-based care with no information on their dying preference locale on a voluntary basis found no difference between the intervention and control group in institutional utilization. On the contrary, dying patients in the intervention group were actively living and pursuing treatment.

\section{Conclusion}

This review confirms the findings of the earlier reviews, ${ }^{40,42}$ that methodological problems still persist in RCT studies. The internal validity in each of these studies is not satisfied, therefore casting doubt on its external validity. The conditions and process of dying that termi- nally-ill patients are enduring inevitably situate them to counter against following high level of evidence of research methodology indicating that one should look into a more appropriate approach. Nevertheless, incorporating a coordinated approach between institutions and noninstitutions to ensure timely referral to palliative care is useful to improving the quality of life for the dying. Such an extensive, comprehensive palliative program bears extra cost. Comparing health-care expenditure between groups utilizing the intensive models of care and those providing usual care (with/without palliative component) requires a well-established and centralized infrastructure to obtain accurate and complete data, and should be conducted in one or multiple sites with the same characteristics. Further investigation is needed to evaluate the cost effectiveness of intensified palliative care programs in the local context.

It is worth noting that data on the quality of life and costs of care of the intensified palliative care programs were obtained during the respective study periods where intervention was being delivered. However, real and lasting improvement in quality of life of the dying, and a complete overview of the costs of care can only be determined through evaluation over a longer period.

\section{Recommendation}

The multiple and persistent methodological issues in generating a high level of evidence on interventions in palliative care on the vulnerable population is an impetus for us to seek more appropriate methodologies that allow results to be generalized and compared across nations.

The wide spectrum of research in epidemiology offers a solution in using an epidemiologic approach, for instance, the surveillance system methodology, which has received unprecedented recognition of its importance of not only monitoring infectious diseases, pandemics or bioterrorism threats, ${ }^{59-60}$ but also to the extent of applying it to palliative care research. ${ }^{61-64}$ The surveillance epidemiology could focus on certain distinctive aspects of palliative care research and cover large-scale public health interventions to improve the quality of life of the dying elderly, and further informing healthcare providers of end-of-life plan. It may offer cost-effective alternatives to primary data collection ${ }^{61}$ that needs to be evaluated over time because costs associated with end of life care are likely to accrue over a longer period of time ${ }^{25-26}$ need a larger sample ${ }^{30}$ and vary by diagnosis. ${ }^{65-67}$ Furthermore, the surveillance network recognizes and manages population-based data to which one can apply observational studies such as recruiting a prospective cohort to monitor long-term multiple effects of exposure/s to the model/s of PCS and establish a clear temporal relationship between the exposure and outcome. $^{68}$

\section{Acknowledgement}

The author thanks the NUHS Medical Publications Support Unit, Singapore, for assistance in the preparation of this manuscript, and former research staff in the 
School of Medicine, National University of Singapore for their initial assistance. My appreciation extends to the team in the Information Specialist Health Technology Assessment, MOH for their advice on developing a systematic review. Comments from the Editors and Referees help to improve this paper.

\section{References}

1. WHO. Ageing and Life Course. Geneva: World Health Organization, 2012.

2. Department of Economic and Social Affairs, United Nations. Magnitude and Speed of Population Ageing. In: World Population Ageing 19502050. New York: Population Division, DESA, United Nations; 2002:11-3.

3. Omran AR. The epidemiologic transition. A theory of the epidemiology of population change. Milbank Mem Fund $Q$ 1971;49:509-38.

4. Omran AR. The epidemiologic transition: a theory of the epidemiology of population change. 1971. Milbank $Q$ 2005;83:731-57.

5. WHO. The World Top Ten Causes of Death. Geneva: World Health Organization, 2012.

6. Maaten S, Kephart G, Kirkland S, Andreou P. Chronic disease risk factors associated with health service use in the elderly. BMC Health Serv Res 2008;8:237.

7. Van den Block L, Deschepper R, Drieskens K, Bauwens S, Bilsen J, Bossuyt N, et al. Hospitalisations at the end of life: using a sentinel surveillance network to study hospital use and associated patient, disease and healthcare factors. BMC Health Serv Res 2007;7:69.

8. Alemayehu B, Warner KE. The lifetime distribution of health care costs. Health Serv Res 2004;39:627-42.

9. Tibi-Lévy Y, Le Vaillant M, de Pouvourville G. Determinants of resource utilization in four palliative care units. Palliat Med 2006;20:95-106.

10. Dixon T, Shaw M, Frankel S, Ebrahim S. Hospital admissions, age, and death: retrospective cohort study. BMJ 2004;328:1288.

11. McGrail K, Green B, Barer ML, Evans RG, Hertzman C, Normand C. Age, costs of acute and longterm care and proximity to death: evidence for 1987-88 and 1994-95 in British Columbia. Age Ageing 2000;29:249-53.

12. Barnato AE, McClellan MB, Kagay CR, Garber AM. Trends in inpatient treatment intensity among Medicare beneficiaries at the end of life. Health Serv Res 2004;39:363-75.

13. Lubitz JD, Riley GF. Trends in Medicare payments in the last year of life. $N$ Engl $J$ Med 1993;328:1092-6.
14. Earle CC, Park ER, Lai B, Weeks JC, Ayanian $\mathrm{JZ}$, Block S. Identifying potential indicators of the quality of end-of-life cancer care from administrative data. J Clin Oncol 2003;21:1133-8.

15. Iezzoni LI. Assessing quality using administrative data. Ann Intern Med 1997;127(8 Pt 2):66674.

16. Barbera L, Paszat L, Chartier C. Death in hospital for cancer patients: an indicator of quality of end-of-life care. Palliat Med 2005;19:435-6.

17. Mezey M, Dubler NN, Mitty E, Brody AA. What impact do setting and transitions have on the quality of life at the end of life and the quality of the dying process? Gerontologist 2002;42 Spec No 3:54-67.

18. Townsend J, Frank AO, Fermont D, Dyer S, Karran $\mathrm{O}$, Walgrove $\mathrm{A}$, et al. Terminal cancer care and patients' preference for place of death: a prospective study. BMJ 1990;301:415-7.

19. Gozalo PL, Miller SC. Hospice enrollment and evaluation of its causal effect on hospitalization of dying nursing home patients. Health Serv Res 2007;42:587-610.

20. Serra-Prat M, Gallo P, Picaza JM. Home palliative care as a cost-saving alternative: evidence from Catalonia. Palliat Med 2001;15:271-8.

21. Gozalo PL, Miller SC, Intrator O, Barber JP, Mor $\mathrm{V}$. Hospice effect on government expenditures among nursing home residents. Health Serv Res 2008;43(1 Pt 1):134-53.

22. Aiken LS, Butner J, Lockhart CA, Volk-Craft BE, Hamilton G, Williams FG. Outcome evaluation of a randomized trial of the PhoenixCare intervention: program of case management and coordinated care for the seriously chronically ill. J Palliat Med 2006;9:111-26.

23. Allen RS, Hilgeman MM, Ege MA, Shuster JL Jr, Burgio LD. Legacy activities as interventions approaching the end of life. $J$ Palliat Med 2008;11:1029-38.

24. Bakitas M, Lyons KD, Hegel MT, Balan S, Brokaw FC, Seville J, et al. Effects of a palliative care intervention on clinical outcomes in patients with advanced cancer: the Project ENABLE II randomized controlled trial. JAMA 2009;302:741 $-9$.

25. Brumley R, Enguidanos S, Jamison P, Seitz R, Morgenstern N, Saito S, et al. Increased satisfaction with care and lower costs: results of a randomized trial of in-home palliative care. $J \mathrm{Am}$ Geriatr Soc 2007;55:993-1000.

26. Brumley RD, Enguidanos S, Cherin DA. Effectiveness of a home-based palliative care program for end-of-life. J Palliat Med 2003;6:715-24. 
27. Du Pen SL, Du Pen AR, Polissar N, Hansberry J, Kraybill BM, Stillman $\mathrm{M}$, et al. Implementing guidelines for cancer pain management: results of a randomized controlled clinical trial. J Clin Oncol 1999;17:361-70.

28. Zimmer JG, Groth-Juncker A, McCusker J. A randomized controlled study of a home health care team. Am J Public Health 1985;75:134-41.

29. Hughes SL, Weaver FM, Giobbie-Hurder A, Manheim L, Henderson W, Kubal JD, et al. Effectiveness of team-managed home-based primary care: a randomized multicenter trial. JAMA 2000;284:287785 .

30. Engelhardt JB, McClive-Reed KP, Toseland RW, Smith TL, Larson DG, Tobin DR. Effects of a program for coordinated care of advanced illness on patients, surrogates, and healthcare costs: a randomized trial. Am J Manag Care 2006;12:93-100.

31. Grande GE, Todd CJ, Barclay SI, Farquhar MC. Does hospital at home for palliative care facilitate death at home? Randomised controlled trial. BMJ 1999;319:1472-1475.

32. Detering KM, Hancock AD, Reade MC, Silvester W. The impact of advance care planning on end of life care in elderly patients: randomised controlled trial. BMJ 2010;340:c1345.

33. Jordhoy MS, Fayers P, Loge JH, Saltnes T, AhlnerElmqvist M, Kaasa S. Quality of life in advanced cancer patients: the impact of socio-demographic and medical characteristics. $\mathrm{Br} \quad J$ Cancer 2001;85:1478-85.

34. Jordhoy MS, Fayers P, Saltnes T, Ahlner-Elmqvist M, Jannert M, Kaasa S. A palliative-care intervention and death at home: a cluster randomized trial. Lancet 2000;356:888-93.

35. Keefe FJ, Ahles TA, Sutton L, Dalton JA, Baucom, Pope MS, et al. Partner-guided cancer pain management at the end of life: a preliminary study. J Pain Symptom Manage 2005;29:263-72.

36. Molloy DW, Guyatt GH, Russo R, Goeree R, O'Brien BJ, Bedard M, et al. Systematic implementation of an advance directive program in nursing homes: a randomized controlled trial. JAMA 2000;283:1437-44.

37. Northouse LL, Mood DW, Schafenacker A, Montie JE, Sandler HM, Forman JD, et al. Randomized clinical trial of a family intervention for prostate cancer patients and their spouses. Cancer 2007;110:2809-18.

38. Raftery JP, Addington-Hall JM, MacDonald LD, Anderson HR, Bland JM, Chamberlain J, et al. A randomized controlled trial of the cost-effectiveness of a district coordinating service for terminally ill cancer patients. Palliat Med 1996;10:151-61.

39. Temel JS, Greer JA, Muzikansky A, Gallagher ER,
Admane S, Jackson VA, et al. Early palliative care for patients with metastatic non-small-cell lung cancer. N Engl J Med 2010;363:733-42.

40. Zimmermann C, Riechelmann R, Krzyzanowska M, Rodin G, Tannock I. Effectiveness of specialized palliative care: a systematic review. JAMA 2008;299:1698-709.

41. Kaasa S, Loge JH. Quality of life in palliative care: principles and practice. Palliat Med 2003;17:11-20.

42. Thomas RE, Wilson D, Sheps S. A literature review of randomized controlled trials of the organization of care at the end of life. Can J Aging 2006;25:271-93.

43. Hearn J, Feuer D, Higginson IJ, Sheldon T. Systematic reviews. Palliat Med 1999;13:7580 .

44. Lorenz KA, Lynn J, Morton SC, Sydney M, Shugarman LM, Wilkinson A, et al. Methodological approaches for a systematic review of end-of-life care. J Palliat Med 2005;8 Suppl $1:$ S4-11.

45. Moher R, Liberati A, Tetzlaff J, Altman DG; the PRISMA Group. Preferred Reporting Items for Systematic Reviews and MetaAnalyses: The PRISMA Statement. Ann Intern Med 2009; 151:264-9.

46. Green S, Higgins JPT, Alderson P, Clarke M, Mulrow CD, Oxman AD. Chapter 1: What is a systematic review? In: Higgins JPT, Green S, eds. Cochrane Handbook for Systematic Reviews of Interventions, Version 5.0.0. The Cochrane Collaboration; updated February 2008. www.cochrane-handbook.org. (accessed July 2012).

47. WHO. Cancer. WHO Definition of Palliative Care. Geneva: World Health Organization, 2012.

48. Cook AM, Finlay IG, Edwards AGK, Hood K, Higginson IJ, Goodwin DM, et al. Efficiency of Searching the Grey Literature in Palliative Care. J Pain Sympt Manag 2001; 22:797-801.

49. Scottish Intercollegiate Guidelines Network. SIGN 50. A Guideline Developer's Handbook. Edinburgh: Scottish Intercollegiate Guidelines Network, 2008.

50. Candy B, Holman A, Leurent B, Davis S, Jones L. Hospice care delivered at home, in nursing homes and in dedicated hospice facilities: A systematic review of quantitative and qualitative evidence. Int $J$ Nurs Stud 2011;48:121-133.

51. Candy B, Jones L, Drake R, Leurent B, King $\mathrm{M}$. Interventions for supporting informal caregivers of patients in the terminal phase of a 
disease. Cochrane Database Syst Rev 61 2011;6:CD007617.

52. Higginson IJ, Evans CJ. What is the evidence that palliative care teams improve outcomes for cancer patients and their families? Cancer $J$ 2010;16:42335 .

53. Higginson IJ, Finlay IG, Goodwin DM, Hood K, Edwards AGK, Cook A, et al. Is There Evidence That Palliative Care Teams Alter End-of-Life Experiences of Patients and Their Caregivers? J Pain Symptom Manage 2003;25:150-68.

54. Zafar SY, Currow DC, Daugherty CK, Abernethy AP. Standards for palliative care delivery in oncology settings. Cancer J 2010;16:436-43.

55. Lorenz KA, Lynn J, Dy SM, Shugarman LR, Wilkinson, A, Mularski RA, et al. Evidence for improving palliative care at the end of life: a systematic review. Ann Intern Med 2008;148:147-59.

56. Higginson IJ, Finlay I, Goodwin DM, Cook AM, Hood K, Edwards AG, et al. Do hospital-based palliative teams improve care for patients or families at the end of life? J Pain Symptom Manage 2002;23:96 $-106$.

57. Arno PS, Levine C, Memmott MM. The economic value of informal care giving. Health Aff (Millwood) 1999; $18: 182-8$.

58. Robinson BE, Pham H. Cost-effectiveness of hospice care. Clin Geriatr Med 1996;12:417-28.

59. Castillo-Salgado C. Trends and directions of global public health surveillance. Epidemiol Rev 2010;32:93-109.

60. Quinn TC, Samet JM. Epidemiologic approaches to global health. Epidemiol Rev 2010;32:1-4.
61. O'Sullivan EM. Using epidemiological surveillance systems and routine data sets to study place of care and place of death: strengths and weaknesses. Palliat Med 2011;25:94-6.

62. Engels EA, Pfeiffer RM, Ricker W, Wheeler W, Parsons R, Warren JL. Use of surveillance, epidemiology, and end results-medicare data to conduct case-control studies of cancer among the US elderly. Am J Epidemiol 2011;174:860-70.

63. Rao JK, Anderson LA, Smith SM. End of life is a public health issue. Am $J$ Prev Med 2002;23:215-20.

64. Rao JK, Abraham LA, Anderson LA. Novel approach, using end-of-life issues, for identifying items for public health surveillance. Prev Chronic Dis 2009;6:A57.

65. Campbell DE, Lynn J, Louis TA, Shugarman LR. Medicare program expenditures associated with hospice use. Ann Intern Med 2004;140:26977.

66. Pyenson B, Connor S, Fitch K, Kinzbrunner B. Medicare cost in matched hospice and nonhospice cohorts. $J$ Pain Symptom Manage 2004;28:200-10

67. Brumley RD, Enguidanos S, Hillary K. The Palliative Care Program. Perm J 2003;7:7-12.

68. Boutou-Kempf O, Marchand JL, Radauceanu A, Witschger O, Imbernon E; Group Health Risks of Nanotechnologies. Development of a French epidemiological surveillance system of workers producing or handling engineered nanomaterials in the workplace. J Occup Environ Med 2011;53 (6 Suppl):S103-7. 